\title{
Serum progesteron induced blocking factor (PIBF) level in Mus Musculus as endothelial dysfunction model and given mild regular exercise
}

Cite as: AIP Conference Proceedings 2108, 020022 (2019); https://doi.org/10.1063/1.5109997 Published Online: 04 June 2019

Meitria Syahadatina Noor, Budi Santoso, Triawanti, and Widjiati

\section{ARTICLES YOU MAY BE INTERESTED IN}

Effect of malaria infection to ovary's oxidative stress in Mus musculus AIP Conference Proceedings 2108, 020028 (2019); https://doi.org/10.1063/1.5110003

Early detection of neonatal sepsis using fourier transformation infrared spectroscopy (FTIR) AIP Conference Proceedings 2108, 020026 (2019); https://doi.org/10.1063/1.5110001

Effect of chronic lead exposure on bone using ATR-FTIR spectroscopy

AIP Conference Proceedings 2108, 020025 (2019); https://doi.org/10.1063/1.5110000

\section{Conference Proceedings}

Get $30 \%$ off all

Enter Promotion Code P/DF=30 at checkout \section{print proceedings!}




\title{
Serum Progesteron Induced Blocking Factor (PIBF) Level In Mus Musculus As Endothelial Dysfunction Model And Given Mild Regular Exercise
}

\author{
Meitria Syahadatina Noor ${ }^{1 *}$, Budi Santoso ${ }^{2}$, Triawanti ${ }^{3}$, Widjiati $^{4}$ \\ ${ }^{l}$ Department of Public Health, Faculty of Medicine Lambung Mangkurat University, Jl. Veteran Banjarmasin, \\ Indonesia \\ ${ }^{2}$ Department of Obstetry Gynaecology, Faculty of Medicine Airlangga University, Jl. Prof Moestopo 47 \\ Surabaya 60132 Indonesia \\ ${ }^{3}$ Department of Biochemistry, Faculty of Medicine Lambung Mangkurat University, Jl. Veteran Banjarmasin, \\ Indonesia \\ ${ }^{4}$ Department of Embriology, Faculty of Veterinary Airlangga University, Campus C Mulyorejo, Surabaya, \\ Indonesia
}

*Corrresponding author: drmeitria@yahoo.com

\begin{abstract}
Maternal mortality rate (MMR) in Indonesia is still high. One of the causes of MMR in Indonesia 20102013 was hypertension in pregnant (preeclampsia). Effect of preeclampsia was a complication for mother and baby. One of the mechanisms of preeclampsia was immune response, there were natural killer cells which induced inflammation. PIBF was a pregnancy protector factor by inhibiting NK lymphocytes and increasing antiinflammation. Mild regular exercise induced IL6 to make IL10 higher. This research's objective was to analyze serum PIBF level because of mild regular exercise in Mus musculus as endothelial dysfunction model induced preeclampsia. This research was true experimental using post test only with control group design. This research consisted of 4 groups: K1 (normal pregnant mice), K2 (endothelial dysfunction model), K3 (endothelial dysfunction model with mild regular exercise since early pregnant), and K4 (endothelial dysfunction model with mild regular exercise since 1 week before pregnant). The exercise used a treadmill without angle for 18 minutes once in 2 days for 2 weeks. The results were serum PIBF level in K1 was 11,982 ng/ml, in K2 was 11,609 ng/ml, in K3 was 7,256 $\mathrm{ng} / \mathrm{ml}$, and in K4 was $19,731 \mathrm{ng} / \mathrm{ml}$. Data distribution was not in normal, so data were analyzed by Kruskal Wallis Test with $\alpha=0,05$. The result was no significant differences of serum PIBF level $(p=0,076)$. The conclusion was mild regular exercise had not increased serum PIBF level yet significantly.
\end{abstract}

Keywords: mild regular exercise, endhotelial dysfunction model, serum PIBF

\section{INTRODUCTION}

Preeclampsia was syndrome which consisted of hypertension (blood pressure $\geq 140 / \geq 90 \mathrm{mmHg}$ ) and proteinuria ( $\geq 0,3$ gram $/ 24$ hours). It happened after 20 weeks of pregnant [1]. Data of Ministry of Health showed that in 2010-2013 hypertension was the second cause of maternal mortality rate in Indonesia after hemorrhage [2]. Data of Ulin Hospital in 2014 showed that preeclampsia/eclampsia in January-June was 181 cases, in July-December was 187 cases [3]. The next year, data of preeclampsia/eclampsia in January-June 2015 was 159 cases, in July-December was 160 cases [4].

International Conference on Bioinformatics and Nano-medicine from Natural Resources for Biomedical Research AIP Conf. Proc. 2108, 020022-1-020022-4; https://doi.org/10.1063/1.5109997 Published by AIP Publishing. 978-0-7354-1840-0/\$30.00 
The effect of preeclampsia was a complication for mother and fetus. Complications for mother were HELLP syndrome, coagulopathy, cerebral dysfunction, renal abnormality, and maternal mortality. Effects for fetus were low birth weight, growth retardation in fetus, and intrauterine fetal death [5].

Mechanism of preeclampsia related to inflammation [6]. It was induced by body that recognized zygote as nonself, so it activated natural killer (NK) cells. NK cells induced inflammation [7]. Research of Szarka et al. and Vitoratos showed that there were increasing of proinflammation cytokine such as tumor necrosis factor- $\alpha$ $(\mathrm{TNF}-\alpha)$, interferon gamma (IFN- $\gamma$ ) and decreasing of anti-inflammation such as interleukin 10 (IL10) $[1,8]$.

Unbalanced of IFN- $\gamma$ and IL 10 level induced placental ischemia. Placental ischemia induced production of anti angiogenic factor that would inhibit proangiogenic factor. That process caused endothelial dysfunction as the early process of preeclampsia [7]. Factor that could protect pregnant from inflammation was progesterone induced blocking factor (PIBF). This factor inhibited NK cells and increased anti-inflammation [9].

Prevention of preeclampsia had not given yet. One of the preventions of preeclampsia was exercise [10]. Research of Hopps et al. showed that regular exercise or regular exercise with anti-inflammation therapy decreased proinflammation cytokines such as TNF- $\alpha$ and IL-1 $\beta$, and increased anti-inflammation such as IL10 and IL4. That mechanism was assumed could be given as prevention of preeclampsia [11]. Exercise could increase anti-inflammation, so serum PIBF level was assumed to increase as description of protector factor in pregnant. Until now, research to know about serum PIBF level in Mus musculus as endothelial dysfunction model that was given mild regular exercise had not done yet, so we need to do this research.

\section{MATERIAL AND METHODS}

Design of this research was true experimental with post test only with control group design. This research used female Mus musculus which was healthy, with age of 3 months, and weight of 15-25 grams. The number of Mus musculus were 10/group.

Research groups were 4 groups, consisted of normal pregnant group (K1), endothelial dysfunction model group (K2), endothelial dysfunction model group with mild regular exercise since early pregnant (K3), and endothelial dysfunction model group with mild regular exercise since 1 week before pregnant (K4). Variables which were examined were serum PIBF level.

The dose that could block placenta QA2 expression as endothelial dysfunction model was 50 ng. Anti QA2 was injected into pregnant Mus musculus $10 \mathrm{ng}(0,1 \mathrm{ml})$ intraperitoneally every day in 1 st day of pregnant until the 5th day of pregnant. Mild regular exercise was given from the first day of pregnant (K3) and from 1 week before pregnant (K4). It was given for until 2 weeks of gestation once in 2 days.

The type of mild regular exercise was treadmill without angulation. Its speed was $14 \mathrm{~cm} / \mathrm{second}$, its duration was 15 minutes. It started with $7 \mathrm{~cm} / \mathrm{second}$ for 1 minute, $11 \mathrm{~cm} /$ second for 2 minutes, and $14 \mathrm{~cm} / \mathrm{second}$ for 15 minutes. Total duration was 18 minutes.

All of research groups were terminated in the 19th day of pregnancy. Serum was taken and examined by Elisa method to know serum PIBF level.

Data were analyzed by one way ANOVA test if the data were in normal distribution with $\alpha=5 \%$. If the data were not in normal distribution, data were analyzed by Kruskal Wallis with $\alpha=5 \%$. 
RESULTS AND DISCUSSION

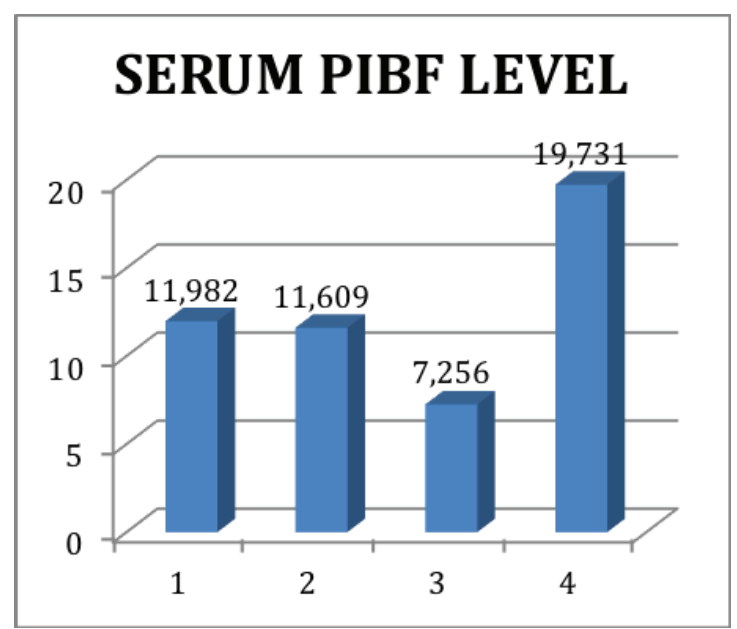

FIGURE 1. Mean of serum PIBF level (ng/ml)

Figure 1 showed that serum PIBF level in K1 (normal pregnant) was 11,982 ng/ml. It was higher than K2 (endothelial dysfunction model) $11,609 \mathrm{ng} / \mathrm{ml}$. That data showed that protector factor in normal pregnant was higher than in preeclampsia. serum PIBF level in mild regular exercise 1 week before pregnant was the highest $(\mathrm{K} 4=19,731 \mathrm{ng} / \mathrm{ml})$. It means that mild regular exercise since 1 week before pregnant could give protector effect by increasing anti-inflammation. Protecting factor was showed by high serum PIBF level. It was described in K4 inhibited NK cells and produced anti-inflammation.

Data of this research was not in normal distribution, so statistic analyzes used Kruskal Wallis Test with $\alpha=$ $5 \%$. The result was $\mathrm{p}=0,076$, there were no significant differences of serum PIBF level in 4 groups.

This result was not the same with research of Hopps et. al. that stated that exercise could increase antiinflammation significantly [11]. This fact was caused by the type of exercise, duration of exercise, the length of exercise or condition of pregnant. Type of research in this research was treadmill without angle, maybe we should try to examine with downhill type of treadmill. Duration and the lenght of exercise could be adjusted with the type of exercise.

Previous researches about exercise without pregnant were discussed more than researches about exercise with pregnant. So we need to investigate about exercise in pregnant condition to know the type, duration and the length of exercise that could be used in pregnant.

\section{CONCLUSION}

The conclusion was mild regular exercise had not increased serum PIBF level yet significantly, but it could increase serum PIBF level based on descriptive data.

\section{ACKNOWLEDGEMENTS}

We said thanks to Embryology Department Airlangga University as the location of this research. 


\section{REFERENCES}

1. Vitoratos, N., Hassiakos, D., dan Iavazzo, C., Review article: molecular mechanisms of preeclampsia. Journal of Pregnancy. 2012. Volume 2012. 1-5.

2. Kementerian Kesehatan RI., Pusat Data dan Informasi Kementerian Kesehatan RI: Situasi Kesehatan Ibu, Jakarta: Pusdatin Kemenkes RI., (2014).

3. Rumah Sakit Umum Daerah Ulin Banjarmasin, Laporan Harian/Bulanan Kejadian Preeklamsia tahun 2014, Banjarmasin: Ruang Bersalin RSUD Ulin Banjarmasin, (2014).

4. Rumah Sakit Umum Daerah Ulin Banjarmasin, Laporan Harian/Bulanan Kejadian Preeklamsia tahun 2015, Banjarmasin: Ruang Bersalin RSUD Ulin Banjarmasin, (2015)

5. Matthiesen, L., Berg G., Ernerudh J., Ekerfelt C., Jonnson Y., dan Sharma S., Immunology of Preeclampsia. Chem Immunol Allergy. 2005. Vol 89, 49-61.

6. Genest, D.S., Falcao S., Gutkowska J., dan Lavoie JL., Impact of exercise training on preeclampsia, potential preventive mechanism. Hypertension. 2012. 60, 1104-1109.

7. Laresgoiti-servitje, E., Lopez N.G., dan Olson D.M., An immunological insight into the origins of preeclampsia. Human Reproduction Update. 2010. Vol 16 no. 5, 510-524.

8. Szarka A., Riko J., Lazar L., Beko G., dan Molvarec A., Circulating cytokines, chemokines and adhesion molecules in normal pregnancy and preeclampsia determined by multiplex suspension array. BMC Immunology. 2010. 11 (59), 1-9.

9. Beta J., Szekeres-Bartho J., Skyfta E., Akolekar R., and Nikolaides KH., Maternal serum progesteroneinduced blocking factor at 11-13 weeks' gestation in spontaneous early preterm delivery. Fetal Diagn Ther. 2011. 29, 197-200.

10. Moura, SBMH., Lopes LM., Murthi P., dan Costa FDS., Review article: prevention of preeclampsia. Journal of Pregnancy. 2012. 1-9.

11. Hopps, E., Canino, B., dan Caimi, G., Effects of exercise on inflammation markers in type 2 diabetic subjects. Acta Diabetol. 2011. 48, 183-189. 